\title{
Altered innate functions of myeloid dendritic cells in ANCA-associated vasculitis
}

\author{
Cécile Braudeau ${ }^{1,2}$, Antoine Néel ${ }^{2,3}$, Marie Rimbert ${ }^{1,2}$, Mohamed Hamidou $^{2,4}$, Régis Josien ${ }^{1,2,4^{*}}$ \\ From 7th European Workshop on Immune-Mediated Inflammatory Diseases \\ Noordwijk aan Zee, the Netherlands. 28-30 November 2012
}

\section{Background}

Dendritic cells (DC) are critical effectors of innate and adaptive immunity, acting both as sentinels that detect the presence of pathogens and as key antigen-presenting cells that regulate the adaptive immune response. Therefore, DC play a crucial role in the control of autoimmune responses. We previously showed that blood DC numbers were strongly reduced in ANCA-associated vasculitis (AAV) likely due to their recruitment in tissues. Here, we assessed the ex vivo responsiveness of blood DC from AAV-patients to Toll-like receptors (TLRs) stimulation.

\section{Materials and methods}

Blood samples from 10 untreated patients with AAV during flares and before any immunosuppressive treatment (AP) were analyzed, along with 9 AAV patients in remission (RP) and 11 age-matched healthy controls (HC). Intracellular cytokine (IL-12, TNF- $\alpha$, IFN- $\alpha$ ) production by blood DC was assessed by 8 -colors flow cytometry after stimulation by Toll-like receptors of whole blood samples.

\section{Results}

We found that myeloid DC (mDC) from patients in acute phase exhibited a decreased IL-12 production after TLR3, 4 and $7 / 8$ stimulation compared to patients in remission and healthy controls. These mDC also produced less TNF- $\alpha$ after TLR3 stimulation. Moreover, we observed a reduction in the frequency TNF $\alpha$-producing plasmacytoid $\mathrm{DC}(\mathrm{pDC})$ upon TLR7/8 triggering in AP patients compared to RP patients and HC.

\section{Conclusion}

Our data show that circulating $\mathrm{mDC}$ from patients with AAV exhibited an altered response to several TLR ligands, with a notable decrease in IL-12 production.

${ }^{1} \mathrm{CHU}$ Nantes, Laboratoire d'Immunologie, Nantes, France

Full list of author information is available at the end of the article
These unexpected results suggest the innate functions of DC especially in response to pathogens are impaired during AAV.

\section{Author details}

'CHU Nantes, Laboratoire d'Immunologie, Nantes, France. ${ }^{2}$ INSERM Center of Research in Transplantation and Immunology, UMR 1064, Nantes, France. ${ }^{3} \mathrm{CHU}$ Nantes, Service de Médecine Interne, Nantes, France. ${ }^{4}$ Université de Nantes, Faculté de Médecine, Nantes, France.

Published: 28 November 2012

doi:10.1186/1479-5876-10-S3-P20

Cite this article as: Braudeau et al: Altered innate functions of myeloid dendritic cells in ANCA-associated vasculitis. Journal of Translational Medicine 2012 10(Suppl 3):P20.

Submit your next manuscript to BioMed Central and take full advantage of:

- Convenient online submission

- Thorough peer review

- No space constraints or color figure charges

- Immediate publication on acceptance

- Inclusion in PubMed, CAS, Scopus and Google Scholar

- Research which is freely available for redistribution

\section{(Ciomed Central}

